\title{
DETERMINATION OF CARBOHYDRATES IN ANIMAL FOODS AS SEVEN FRACTIONS
}

\author{
Maija-Liisa Salo \\ Department of Animal Nutrition and Husbandry, University of Helsinki
}

Received December 12, 1960

Very few research workershave published analytical data on several individual carbohydrates or groups of carbohydrates in a certain vegetable material. EKELUND (1949) has studied especially the carbohydrates of different hays. LAIDLAW \& Reid (1952), Wylam (1954), and HaRwood (1954) have investigated in detail the determination of carbohydrates in grasses and clover. Among earlier investigators in this field are König (1930), and Waksman \& Stevens (1930).

\section{Experimental}

The present work describes the determination of carbohydrates as the following fractions: 1) monosaccharides, 2) di-, and oligosaccharides, 3) fructosan, 4) starch, 5) hemicellulose, 6) cellulose, and 7) uronides. The first six groups are determined successively on the same sample, and the final residue of the treatments is considered to be lignin. The purpose of this work was to develop a system of analysis with which the fractionation performed would involve only a moderate amount of work. In addition to the above mentioned fractionation the following determinations have been made: crude fat, crude protein, ash, and nitrogen- and carbohydrate-free organic matter soluble in cold water. In an alternative system monosaccharides, sucrose, and fructosan are determined as a group. This paper gives only the outlines of the study since it will be described later in greater detail.

\section{Methods}

Mono-, di-, and oligosaccharides. - A sample of $1 \mathrm{~g}$ is extracted with $80 \%$ ethanol in the Soxhlet apparatus for five hours. The ethanol is removed under reduced pressure at $25-30^{\circ}$, and the residue is filtered through a filter paper and washed with water. The volume is adjusted to $100 \mathrm{ml}$ (or $200 \mathrm{ml}$ ). $50 \mathrm{ml}$ of the filtrate is purified and deionized by shaking it mechanically with a mixture of Duolite A-7 and Duolite C-3 (2 g of each resin) for an hcur. The purified filtrate is analyzed 
for reducing sugars with the Somogy method (1945), and for fructose with the colorimetric method of ARni \& Percival (1951). An aliquot of the purified filtrate is acidified with suphuric acid to $0.02 \mathrm{~N}$ and heated in a boiling-water bath for 30 minutes to hydrolyze sucrose and the main part of the possible oligosaccharides. After neutralization the reducing sugars are determined. The result for the reducing sugars without a hydrolysis gives the amount of monosaccharides, whereas the difference between the values after and before hydrolysis is calculated as sucrose.

Fructosan - The ethanol-extracted and dried residue is transferred into a 100 $\mathrm{ml}$ Erlenmeyer flask, which is filled with $0.1 \mathrm{~N}$ hydrochloric acid containing $0.1 \%$ pepsin (1:3500). The pepsin is necessary to lower the protein content of the definite residue of all the treatments, i.e. the lignin. The flask is kept at $38^{\circ}$ for about 20 hours with an occasional shaking. The residue is filtered on $a_{3}$ sintered-glass filter, and washed with cold water. An aliquot of the filtrate is neutralized and clarified by shaking it with the mixture of Duolite A-7 and Duolite C-3 as before. The purified solution is analyzed for fructose and as a control measure, also for reducing sugars. The result is expressed as polysaccharides.

Starch - In materials containing starch the pepsin digestion is substituted for a diastase digestion. The possible fructosan can be determined on the same solution. The ethanol-extracted dried residue is transferred into a $100 \mathrm{ml}$ Erlenmeyer flask and boiled with $45 \mathrm{ml}$ water for ten minutes. After cooling $50 \mathrm{ml}$ of $0.4 \%$ diastase solution (Merck, hochgerenigt), and some thymol are added. The flask is kept at $38^{\circ}$ for 24 hours with an occasional shaking. The residue is filtered on a $\mathrm{G}_{3}$ sinteredglass filter or on a close nylon cloth and washed with cold water. An aliquot of the filtrate is acidified with conc. sulphuric acid to $0.7 \mathrm{~N}$, and heated in a boiling-water bath for $2 \frac{1}{2}$ hours. The solution is diluted with an equal volume of water, and neutralized and purified by shaking it with a mixture of a suitable amount of Duolite A-7 and some Duolite C-3. Reducing sugars, and fructose separately, are determined on the filtrate. A blank test of the diastase solution is made similarly.

To obtain an exact value for fructosan it is necessary to analyze the solution for fructose also before the hydrolysis, because a part of the fructose gets decomposed during the hydrolysis. The values are calculated as polysaccharides and the results of blank tests are subtracted.

Hemicellulose - The wet residue from the pepsin or diastase digestion is washed with $100 \mathrm{ml}$ of $0.7 \mathrm{~N}$ hydrochloric acid from the filter into a round-bottomed flask, heated, and shaken in a boiling-water bath for 5 hours. After this it is filtered on a $G_{3}$ sintered-glass filter, the bottom of which is covered with a $1 \mathrm{~mm}$ layer of pumice stone powder to prevent the solid particles from entering the sintered-glass. The filtrate is adjusted to $500 \mathrm{ml}$, and $50 \mathrm{ml}$ of it is neutralized and purified. It is shaken in an Erlenmeyer flask with a mixture of $3 \mathrm{~g}$ Duolite A-7 and $1 \mathrm{~g}$ Duolite C-3 for 30 minutes. $1 \mathrm{~g}$ of Duolite A-7 is added, and the shaking is continued for another 30 minutes. The solution is filtered through a filter paper and the reducing sugars are determined. A part of the purified filtrate is evaporated to a small volume for chromatographic estimation. The proportions of the individual sugars are estimated on the chromatograms and taken into account in the calculating of the hemicellulose. 
Table 1. Analytical data from different

\begin{tabular}{|c|c|c|c|c|c|}
\hline Material & $\begin{array}{l}\text { Monosaccha- } \\
\text { rides }\end{array}$ & Sucrose & Fructosan & Starch & $\begin{array}{c}\text { Hemicellu- } \\
\text { lose }\end{array}$ \\
\hline Timothy, early leaf stage & 7.02 & 5.39 & 13.00 & - & 13.39 \\
\hline Cocksfoot, later leaf stage & 5.56 & 4.98 & 2.94 & - & 14.03 \\
\hline Timothy, in bloom & 5.10 & 2.59 & 1.55 & - & 20.75 \\
\hline Rye, straw & 0.46 & 0.25 & 0.19 & - & 21.48 \\
\hline Red clover, early leaf stage & 6.30 & 0.40 & 0.10 & - & 9.61 \\
\hline,$\quad$ in bud & 8.72 & 1.65 & 0.04 & - & 13.45 \\
\hline in bloom & 5.47 & 1.60 & 0.12 & - & 10.43 \\
\hline Clover meal, leaf stage & 1.84 & 1.56 & 0.65 & - & 10.26 \\
\hline Hay meal, clover + timothy & 3.87 & 3.07 & 0.89 & - & 13.50 \\
\hline Calsifor-silage, cocksfoot + clover & & $0.31^{1}$ & & & 13.84 \\
\hline AIV-silage, clover + timothy & & $0.92^{1}$ & & & 10.77 \\
\hline Swedes & 48.15 & 5.26 & 0.09 & - & 8.47 \\
\hline Sugar beet tops & 25.95 & 5.79 & 0.44 & - & 5.89 \\
\hline Stellaria media & 5.48 & 0.97 & 0.38 & - & 6.25 \\
\hline Wheat bran & 0.40 & 5.55 & 1.10 & 12.81 & 24.32 \\
\hline Soya bean meal & 0.15 & 10.11 & 0.70 & 1.56 & 7.46 \\
\hline Ground-nut cake & 0.27 & 8.71 & 0.42 & 4.25 & 4.46 \\
\hline
\end{tabular}

1 Monosaccharides + sucrose + fructosan

Cellulose - The dried residue from the above treatment is transferred into a 100 $\mathrm{ml}$ beaker. $5 \mathrm{ml}$ of $72 \%$ suphuric acid is added and mixed thoroughly with a glass rod. The beaker is kept at about $20^{\circ}$ for 3 hours with an occasional strirring. The content of the beaker is then transferred into a $300 \mathrm{ml}$ Erlenmeyer flask with $172 \mathrm{ml}$ of water and the solution is refluxed for 4 hours, filtrated through an asbestoslined Gooch crucible, and washed with hot water. The filtrate is filled up to $500 \mathrm{ml}$ and a suitable aliquot is neutralized and purified with Duolite A-7. The reducing sugars are determined on the filtrate and calculated as glucosans.

Lignin - The final residue of the carbohydrate hydrolysis is ignited and the ignition loss is considered as lignin. The lignin from materials containing starch is corrected as regards protein, because in the treatment of these materials the pepsin digestion is omitted.

Uronides - The uronic acids were determined on the original material with the method of Johansson \& Lindberg \& Theander (1954). The results were calculated as uronides.

Other determinations - The nitrogen was determined according to Kjeldahl. Protein factor 6.25 was used. The incineration in the ash determination was made at $700^{\circ}$. In the crude fat determination the samples $(2 \times 1 \mathrm{~g})$ are shaken with 100 $\mathrm{ml}$ of water containing some thymol at about $20^{\circ}$ for 12 hours, filtered on a filter paper, washed with cold water and dried in vacuo at $70^{\circ}$. Subsequently they are extracted in the Soxhlet apparatus with ethanol-benzene for 8 hours. The flask is dried in vacuo at $70^{\circ}$. 


\begin{tabular}{|c|c|c|c|c|c|c|c|}
\hline Cellulose & Uronides & Lignin & Crude fat & Crude protein & Ash & $\begin{array}{l}\text { Water-soluble } \\
\text { N-free non- } \\
\text { organic matter }\end{array}$ & Total \\
\hline 15.93 & 3.50 & 2.33 & 7.97 & 15.17 & 6.42 & 10.20 & 100.32 \\
\hline 16.65 & 4.16 & 3.22 & 7.70 & 21.35 & 9.46 & 10.47 & 100.52 \\
\hline 27.88 & 4.27 & 7.60 & 4.44 & 8.63 & 5.61 & 8.12 & 96.54 \\
\hline 35.88 & 3.78 & 13.44 & 4.03 & 2.78 & 5.95 & 3.50 & 91.74 \\
\hline 9.22 & 9.95 & 2.14 & 8.52 & 26.42 & 9.56 & 15.90 & 98.12 \\
\hline 14.88 & 9.77 & 5.28 & 7.39 & 17.87 & 6.23 & 14.59 & 99.87 \\
\hline 18.18 & 10.83 & 7.46 & 5.54 & 15.17 & 7.25 & 14.09 & 96.14 \\
\hline 12.36 & 9.29 & 5.15 & 9.61 & 24.04 & 10.62 & 16.55 & 101.93 \\
\hline 18.65 & 8.24 & 7.80 & 6.54 & 14.74 & 8.70 & 14.78 & 100.78 \\
\hline 25.13 & 6.50 & 11.31 & 7.31 & 14.35 & 11.54 & 6.74 & 97.03 \\
\hline 19.96 & 9.19 & 6.21 & 9.32 & 17.39 & 9.19 & 15.88 & 98.83 \\
\hline 6.79 & 8.92 & 0.54 & 2.96 & 11.46 & 5.32 & 2.00 & 99.96 \\
\hline 7.13 & 8.33 & 1.53 & 3.94 & 15.56 & 14.15 & 8.31 & 97.02 \\
\hline 11.11 & 9.11 & 1.93 & 7.48 & 26.96 & 20.96 & 7.48 & 98.11 \\
\hline 8.53 & 3.10 & 5.68 & 5.86 & 16.47 & 6.28 & 6.60 & 96.70 \\
\hline 8.07 & 4.46 & 1.01 & 4.29 & 47.80 & 5.79 & 9.47 & 100.87 \\
\hline 4.46 & 4.37 & 2.60 & 6.39 & 55.22 & 6.32 & 5.93 & 103.40 \\
\hline
\end{tabular}

In addition the water-soluble $\mathrm{N}$-free non-carbohydrate organic matter was determined by shaking the sample with water as mentioned above. The insoluble residue was filtered on a filter paper, washed with cold water, and determined for dry matter and ash. Another sample was treated similarly and analyzed for nitrogen to obtain the crude protein of the residue. The corresponding water-soluble fractions were calculated by subtraction. From the water-soluble $\mathrm{N}$-free organic matter the amounts of monosaccharides, sucrose, and fructosan were subtracted.

The determination of water-soluble carbohydrates as a group - The analysis in this case begins with the pepsin-treatment and both the reducing sugars, and fructose separately, are determined on the filtrate. The proportions of mono-, and polysaccharides are calculated in the following manner. All fructose obtained by colorimetric method is calculated as anhydride and multiplied by the factor 0.9 . From the value of reducing sugars that of fructose, as monosaccharide, is subtracted, and the difference is added to the value of fructosan. The analysis is continued extracting the dried residue with ethanol-benzene and determining the hemicellulose, cellulose and lignin in the usual way. This method is not suitable for materials containing starch, because some of the starch is dissolved during the treatment.

\section{Results and discussion}

The results obtained by the fractionation are given in Table 1. It appears from the figures, that in most of the materials the main part of the ethanol-soluble suga rs 
consists of monosaccharides in concentrates, howerer, of sucrose. Only very young grasses seem to contain appreciable amounts of fructosan. The water-soluble carbohydrates have practically disappeared in silages. It also seems that a considerable amount of the sugars disappears during the making of hay meal. The uronides content is about the same at all stages of growth in grasses and red clover, and it may therefore constitute useful index for the estimation of the ratio between the grasses and clovers in hay meal and in silage. The last column shows that the total of the results comes rather close to $100 \%$.

The following arrangement shows the totals of mono-, di-, and oligosaccharides and fructosan determined, A, as three fractions and, B, as a group. (Percentages of dry matter).

\begin{tabular}{lrr} 
& A & \multicolumn{1}{c}{ B } \\
Timothy, early leaf stage & 25.41 & 25.40 \\
Cocksfoot, later leaf stage & 13.48 & 13.09 \\
Red clover, in bud & 10.41 & 10.49 \\
Clover meal, leaf stage & 4.05 & 4.35 \\
Hay meal, clover + timothy & 7.83 & 7.84 \\
Sugar beet tops & 32.18 & 30.67
\end{tabular}

The differences between these two results in grasses and red clovers are very small, within the limit of analytical error. The big difference in the case of the sugar beet tops is due to the fact that the content of monosaccharides in tops is very high, whereas that of sucrose is low, and fructosans are practically absent. Because the fructose has been calculated as polysaccharide, the result is too low. In cases of materials of this kind the amount of monosaccharides as such gives rather exact results.

The purity of the different fractions of carbohydrates was checked with paper chromatography with the following results.

The acid pepsin solution dissolves also a small amount of arabans. The differences between the results obtained by colorimetric fructose determination and those obtaining as reducing sugars were, however, with two exceptions only $0.0-0.3 \%$. The experiment with pure fructose solution showed that $0.1 \mathrm{~N}$ hydrochloric acid does not decompose fructose at $38^{\circ}$.

The determination of starch by a diastase digestion is not very accurate, because a small amount of hemicellulose also dissolves during the process. Thus the starch values may be too high at the expence of hemicellulose. As the diastase preparations contain large amounts of polysaccharides, a blank test on the solutions is always necessary.

The proportions of the individual monosaccharides which compose the hemicellulose can be estimated by the naked eye on the paper chromatograms with such an degree of accuracy that the different reducing powers of individual monosaccharides can be taken into account in the calculation. The main part of the uronides is dissolved during the hemicellulose digestion, but the uronic acids are adsorbed almost completely by the ion-exchange resin when the acid-binding resin is added in two portions, the first of which is sufficient to neutralize the solution. 
The cellulose fraction always contains some xylose and traces of arabinose, in some materials there are also traces of uronic acids and mannose.

The experiments which were made with pure solutions of individual monosaccharides showed that the purification of the solution by ion-exchange resins Duolite A-7 and Duolite C-3 has no effect on the concentration of sugar solutions. The same is true in the neutralization of the acid solution with Duolite A-7, if the resin is fresh. If, however, Duolite A-7 has once been used for neutralization and has been regenerated, it concentrates sugar solutions.

The uronides were calculated as being methoxyl-free and thus the figures are too low. The determination of uronic acids regarding methoxyl would, however, be an inaccurate and tedious process.

The lignin values are somewhat larger than those obtained by the methods with a stronger prehydrolysis (SALO, 1957). It is, however, difficult to decide which method would give the most exact result. The term "ligninn is in any case analytically conventional.

\section{$S u m m a r y$}

An analysis system is described by means of which the carbohydrates of plant materials are successively dissolved, hydrolyzed, and determined as reducing sugars. The uronides are determined on a separate sample. In this manner 7 groups are obtained: 1) monosaccharides, 2) di-, and oligosaccharides, 3) fructosan, 4) starch, 5) hemicellulose, 6) cellulose, 7) uronides. The final hydrolysis residue from the carbohydrate hydrolysis is considered as lignin. Furthermore, crude fat, crude protein, ash, and in cold water soluble $\mathrm{N}$-free non-carbohydrate organic matter are determined. The total of the results of the analyses appears to be approximately $100 \%$.

In an alternative system used by the author, mono-, di-, and oligosaccharides and fructosan are determined as a group. The results are compared with those obtained by fractionation.

The sugar solutions have been purified and neutralized with ion-exchange resins using the bath-method. Duolite A-7 and Duolite C-3 have been found to be suitable for these purposes in experiments which were made with pure solutions of individual sugars.

The purity of different fractions of carbohydrates has been checked by paper chromatography. Also the proportions of individual monosaccharides in a hemicellulose fraction for a more exact calculation of their value for hemicellulose were estimated by chromatography.

\section{REFERENCES}

(1) Arsi, P. C. \& Percival, E. G. 1951. Studies on fructosans. Part 11. Triticin from the rhizomes of couch grass (Triticum repens L.). J. Chem. Soc. 1951: 1822-1830.

(2) Ekelund, S. 1949. Carbohydrates in hay with some analytical methods applied to feeds and foods, especially to hays. Kungl. Landbrukshögskolans Annaler 16:179-327.

(3) HARwood, V. D. 1954. Analytical studies on the carbohydrates of grasses and clovers. V. Development of a method for the estimation of cell-wall polysaccharides. J. Sci Food Agric. 5: 270275 . 
(4) Johansson, A., Lindberg, B. \& Theander, O. 1954. Semimicro determination of uronic acids. Svensk papperstidn. 57: 41-43.

(5) KöNig, J. 1930. Neues Verfahren zur chemischen Untersuchung der Futter- und Nahrungsmittel. Berlin 1930. 65 p.

(6) Laidlaw, R. A. \& Reid, S. G. 1952. Analytical studies on the carbohydrates of grasses and clovers. I. Development of methods for the estimation of the free sugar and fructosan contents. J. Sci. Food Agric. 3: 19-25.

(7) Salo, Maija-Lirsa 1957. Lingin studies. I. Investigations concerning lignin determination. J. Scient. Agric. Soc. Finl. 29: 185-193.

(8) Somogyi, M. 1945. A new reagent for the determination of sugars. J. Biol. Chem. 160 : $61-68$.

(9) Waksman, S. A. \& Stevens, K. R. 1930. A system of proximate chemical analysis of plant materials. Ind. Eng. Chem. Anal. Ed. 2: 167-173.

(10) Wylam, C. B. 1954. Analytical studies on the carbohydrates of grasses and clovers. IV. Further developments in the methods of estimation of mono-, di-, and oligosaccharides and fructosan. J. Sci. Food Agric. 5: 167-172.

SELOSTUS:

HIILIHYDRAATTIEN MÄÄRITTÄMISESTÄ REHUAINEISSA SEITSEMÄNÄ RYHMÄNÄ.

Maija-Litsa Salo

Yliopiston kotieläintieteen laitos, Helsinki

Selostetussa analyysijärjestelmässä on hiilihydraatit asteettain liuotettu ja hydrolysoitu sekä mãäritetty pelkistävänä sokerina. Uronidit on määritetty eri näytteestä. Täten on saatu seitsemän ryhmää: 1) monosakkaridit, 2) di- ja oligosakkaridit, 3) fruktosaanit, 4) tärkkelys, 5) hemiselluloosa, 6) selluloosa, 7) uronidit. Hiilihydraattimääritysten lopullinen hydrolyysijäännös on katsottu ligniiniksi. Lisäksi on määritetty raakarasva, raakaproteiini, tuhka sekä kylmään veteen liukeneva typpi- ja hiilihydraattivapaa orgaaninen aine. Analyysitulosten yhteissumma on erilaisilla rehuaineilla osoittautunut olevan melko lähellä prosenttilukua 100.

Vaihtoehtoisesti on menetelty myös siten, että mono-, di- ja oligosakkaridit sekä fruktosaanit on määritetty yhteismäärityksenä ja tulosta verrattu fraktioimalla saatuun.

Sokeriliuosten puhdistaminen ja neutraloiminen on suoritettu ioninvaihtajilla. Duolite A-7 ja Duolite C-3 on kokeissa todettu tarkoitukseen sopiviksi.

Fraktioiden puhtautta on tarkkailtu paperikromatografian avulla. Kromatogrammeista on myös arvioitu laskua varten eri monosakkaridien osuus hemiselluloosafraktiossa. 